\title{
TRANSFORMASI KELEMBAGAAN KECAMATAN : DILEMA ANTARA TUNTUTAN DAN BATAS KEWENANGAN
}

\author{
Maulana Mukhlis
}

Dosen Fakultas Ilmo Sosial dan Ilmu Pemerintahan Universitas Lampung

\begin{abstract}
Position and authority of the sub-district (head-sub district) underwent a fundamental change since the regional autonomy. Huge demands from society about function in government districts, and community development are not comparable with the authority. Therefore, the formulation of the problem in this research is how the position should be owned by institutional strengthening efforts districts governance? This study aims to determine the capacity (typology) subdistricts, the pattern of organization of districts governance in the middle of the dilemma between the demands of authority boundaries. By measuring the capacity which is owned by the sub-district (budget, authority, infrastructure and human resources) in the administration of sub-district governance so far, can be explained that the problem faced by most sub-districts in Indonesia (or at least in the study area-Mesuji District-) is the narrowness of the V space which shows the capacity owned by the sub-district to be able developing governmental functions, and social development is very marginal. Nevertheless, the majority of people assume that the presence of sub-district is expected to serve in an effort to bring citizens to the state. This condition was also aggravated by the fact that the regents did not give up the authority of distributive and attributive of its authority to the head of sub-district and sub-district institutions as possible in Article 126 of Law 32/2004. Politically, the reluctance to distribute this authority shows that the delegation of authority to the head of sub-district and sub-district institutions can be expected to threaten the political position of regent. Referrals theory suggests that efforts to reposition sub-district can be done through the (a) functional structuralism, (b) redefinition and categorization 'playroom' convenient for subdistrict, (c) strengthening human resources in order to invest long-term leadership and with $(d)$ path social-psychological.
\end{abstract}

Keywords : Typology, Institusional Transformation, Sub-district Reposition

\section{PENDAHULUAN}

Otonomi daerah melalui Undang-Undang Nomor 22 Tahun 1999 dan Undang-Undang Nomor 32 Tahun 2004 yang memberikan bobot kewenangan yang sangat besar kepada bupati/walikota memberikan dampak yang besar terhadap penyelenggaraan pemerintahan daerah dan mengubah secara mendasar praktek-praktek pemerintahan, baik secara struktural, fungsional, maupun kultural dalam tatanan penyelenggaraan pemerintahan daerah. Salah satu perubahan yang sangat esensial dalam perubahan undang-undang tersebut yaitu menyangkut tentang 
kedudukan, tugas pokok dan fungsi kecamatan. Perubahan tersebut secara langsung maupun tidak langsung telah mengubah bentuk organisasi, pembiayaan, pengisian personil, pemenuhan kebutuhan logistik serta akuntabilitas penyelenggaraan kecamatan. Undang-Undang Nomor 5 Tahun 1974 tentang Pokok-Pokok Pemerintahan di Daerah, sosok kecamatan selain sebagai organ pemerintah daerah, juga berkedudukan sebagai wakil pemerintah pusat di daerah. Posisi sebagai "wakil pemerintah pusat di daerah" ini kemudian menjadi titik sentral kekuatan institusi kecamatan. Dengan posisi tersebut, seorang camat merupakan kepala wilayah dan penguasa tunggal di bidang pemerintahan, pembangunan dan kemasyarakatan di wilayahnya. Dengan legitimasi sosial-budaya dan sosial-politik yang sangat kuat, camat mampu memimpin institusi kecamatan guna menjalankan fungsi pemerintahan, pembangunan dan kemasyarakatan hampir tanpa kendala yang berarti.

Regulasi dalam UU 22/1999 dan UU 32/2004 kemudian mengubah pola hubungan dan hierarkhi antara kabupaten kecamatan - desa, dan yang paling berubah adalah kelembagaan kecamatan. Institusi yang selama itu berkedudukan sebagai "penguasa tunggal" wilayah kemudian berubah secara struktural hanya menjadi lembaga perangkat daerah kabupaten.

Kekuasaan dan kewenangan yang dimiliki kecamatan di bidang pemerintahan, pembangunan dan kemasyarakatan ditarik dan didistribusi-kan kepada perangkat daerah lainnya (dinas, badan dan kantor). Seorang camat tidak lagi memiliki kewenangan langsung untuk merencanakan, mengarahkan dan mengendalikan proses pembangunan lintas sektor di wilayahnya. Demikian pula dengan fungsi pelayanan publik, banyak bidang pelayanan publik yang sebetulnya lebih efektif dilaksanakan di kecamatan (lebih dekat, lebih cepat dan lebih terjangkau oleh masyarakat) kemudian dialihkan penanganannya kepada perangkat daerah lainnya. Praktis institusi kecamatan kemudian hanya menjalankan peran dan fungsi koordinatif-administratif semata.

Di sisi lain, dengan kultur yang selama ini terbangun, aparatur kecamatan belum sepenuhnya menyadari tentang perubahan kelembagaan dan kewenangannya itu. Pun demikian dengan masyarakat luas, masyarakat masih menganggap bahwa kecamatan memiliki fungsi kekuasaan dan kewenangan sebagaimana dimiliki lembaga tersebut tempo dulu. Camat dan kecamatan kemudian berada dalam posisi yang dilematis; di satu sisi harus mengakomodir tuntutan dan pengaduan masyarakat, sedangkan di sisi lain kecamatan tidak memiliki kewenangan dan kekuasaan untuk merespon dan menindaklanjuti tuntutan dan pengaduan tersebut.

$$
\text { Jika mengacu kepada }
$$

kewenangan, sebenarnya banyak tuntutan dan pengaduan masyarakat yang merupakan kewenangan dari dinas/instansi teknis di tingkat kabupaten/kota. Namun pada kenyataannya, masih terdapat banyak kelemahan dan keterbatasan pada dinas/instansi sehingga mereka juga tidak dapat menyelesaikan berbagai permasalahan pembangunan, pemerintahan dan kemasyarakatan 
yang ada. Pada akhirnya, terjadi dilema yang menghinggapi camat dan institusi kecamatan. Di satu sisi, tidak mungkin menolak pengaduan masyarakat dan tuntutan tugas serta instruksi dari pimpinan. Namun di sisi lain, kewenangan bertindak dan kekuasaan mengambil keputusan tidak lagi dimiliki akibat perubahan peraturan. Kondisi ini mengakibatkan kegamangan, keraguan bertindak, ketakutan pada resiko dan menimbulkan rasa tidak "percaya diri" yang dialami oleh camat.

Kondisi tersebut pada dasarnya bertentangan dengan upaya peningkatan kualitas pelayanan publik sebagai tujuan dari otonomi daerah. Masyarakat yang seharusnya mendapatkan kemudahan pelayanan justru tidak mendapatkannya karena institusi kecamatan yang selama ini dianggap unit pemerintahan terdekat dengan masyarakat tidak lagi memiliki kewenangan untuk memberikan pelayanan tersebut. Sebenarnya, kesenjangan ini bisa diminimalisir apabila kecamatan memiliki pelimpahan kewenangan langsung dari bupati/walikota untuk melaksanakan tugas dan kewenangan tertentu. Namun sampai saai ini kewenangan ini juga tak kunjung diberikan.

Pada tataran ideal, dengan segala kendala yang dimiliki oleh camat dan institusi kecamatan tersebut, institusi kecamatan harus tetap dipertahankan keberadaan dan keberfungsiannya. Namun jika berbagai kelemahan tersebut tidak dapat diselesaikan, maka pilihan radikal untuk menghilangkan institusi kecamatan dalam sistem tata pemerintahan di daerah dapat menjadi solusi atas berbagai dilema yang dihadapi Berdasarkan hal tersebut, rumusan masalah yang hendak dibahas dalam studi ini adalah bagaimanakah posisi yang harus dimiliki oleh institusi kecamatan dan upaya penguatan ketata-pemerintahan kecamatan dalam rangka memenuhi tuntutan masyarakat dalam bidang pemerintahan, pembangunan dan kemasyarakatan? Secara substansi permasalahan tersebut difokuskan kepada kecamatan di Kabupaten Mesuji Provinsi Lampung sebagai fokus lokasi penelitian ini.

Studi ini bertujuan untuk: (1) mengetahui posisi dan kapasitas kecamatan sebagai basis analisis kemampuan kecamatan tersebut menjalankan fungsinya,

Memetakan penyelenggaraan tata kepemerintahan kecamatan di tengah dilema antara tuntutan dan kewenangan, dan (3) memberikan rekomendasi penguatan (reposisi) kelembagaan kecamatan untuk mampu menyelenggarakan fungsinya secara optimal.

\section{METODE PENELITIAN}

Studi ini menggunakan strategi penelitian Studi Kasus pemerintahan daerah di Kabupaten Mesuji Provinsi Lampung dan Studi Literatur sebagai pembanding. Selain sebagai daerah otonom baru, kabupaten ini juga termasuk kawasan kabupaten rural yang pada kenyataannya lebih memiliki dilema, dinamika dan tantangan tata pemerintahan kecamatan yang lebih kompleks dan dinamis karena rentang kendali masyarakat untuk mendapatkan pelayanan ke kecamatan sangat jauh dan dibatasi oleh keadaan geografis wilayah yang beragam. Strategi atau pendekatan dalam penelitian ini lebih ditekankan pada sifat konstruktifistik dan kualitatif. Dengan sifat 
konstruktifistik, maka hal terpenting yang hendak dihasilkan dari penelitian lapangan adalah pengungkapan makna di balik fakta. Pendekatan kualitatif melalui wawancara mendalam akan menjamin tergalinya pandangan obyektif dari peneliti terhadap fakta yang ada di kecamatan yang terdapat di Kabupaten Mesuji. Data-data yang diperoleh kemudian dianalisis dan diuraikan dalam bentuk naratif dengan tiga fokus utama yakni tipologi atau kapasitas kecamatan, temuan keberadaan prasyarat penyelenggaraan kecamatan dalam konteks kemampuan kecamatan menjalankan fungsinya dan rekomendasi reposisi kecamatan.

\section{PEMBAHASAN}

\subsection{Tipologi (Kapasitas) Kecamatan}

Kecamatan dikatakan mempunyai tipologi A apabila total skor yang diperoleh merupakan akumulasi jumlah indikator pada setiap variabel atau kelompok kriteria dikali bobot dan sub bobot masing-masing variabel dan indikator minimal berjumlah 233, dan suatu kecamatan dikatakan mempunyai tipologi B bila total skor yang diperoleh merupakan akumulasi jumlah indikator pada setiap variabel/kelompok kriteria dikali bobot dan sub bobot masing-masing variabel dan indikator minimal berjumlah 167 dan maksimal 232.

Sedangkan

kecamatan

dikatakan mempunyai tipologi $\mathrm{C}$ bila total skor yang diperoleh merupakan akumulasi jumlah indikator pada setiap variabel/kelompok atau kriteria dikali bobot dan sub bobot masing-masing variabel dan indikator minimal berjumlah 100 dan maksimal berjumlah 166. Setelah diperoleh nilai skor setiap variabel pada seluruh kecamatan, dan 'mengkalikan' nilai skor tersebut dengan bobot (persentase).

Sebagai daerah otonom baru, Pemerintah Kabupaten Mesuji yang terbentuk berdasarkan UndangUndang Nomor 49 Tahun 2008 saat ini terdiri atas 7 (tujuh) Kecamatan yaitu Kecamatan Mesuji, Kecamatan Mesuji Timur, Kecamatan Rawa Jitu Utara, Kecamatan Way Serdang, Kecamatan Simpang Pematang, Kecamatan Panca Jaya, dan Kecamatan Tanjung Raya.

Berdasarkan tabel berikut penentuan perhitungan skor terhadap tipologi Kabupaten Mesuji yang terdiri atas 11 (sebelas) variabel atau indikator, dimana perhitungan skor dan bobot secara keseluruhan dikelompokkan dalam 3 (tiga) tipe yaitu:

1. Tipe A, adalah kecamatan dengan nilai di atas nilai rata-rata tinggi atau interval skor 233 300

2. Tipe $\mathrm{B}$, adalah kecamatan dengan nilai di atas nilai rata-rata sedang atau interval skor 167 - 232

3. Tipe $\mathrm{C}$, adalah kecamatan dengan nilai di atas nilai rata-rata rendah atau interval skor 100 - 166 
Tabel 1

Bobot Pengalian Terhadap Masing-Masing Skor Sub Indikator

\begin{tabular}{|l|c|}
\hline \multicolumn{1}{|c|}{ Sub Indikator } & Nilai Sub Bobot (\%) \\
\hline 1. Luas wilayah & 11,33 \\
2. Persentase penggunaan wilayah & 3,78 \\
\hline 1. Jumlah Penduduk & 7,06 \\
2. Kepadatan penduduk & 4,23 \\
3. Jumlah KK, Lingkungan/Dusun, RW dan RT & 2,82 \\
\hline 1. Rata-rata jarak tempuh & 5,25 \\
2. Rata-rata waktu tempuh & 3,93 \\
3. Jumlah desa & 3,93 \\
\hline 1. Pegunungan, berbukit/berombak atau dataran & 12,11 \\
\hline 1. Jumlah rumah tangga pelanggan telepon & 4,45 \\
2. Sarana penerangan rumah & 3,33 \\
3. Ketersediaan kantor pos dan sejenisnya & 3,33 \\
\hline 1. Panjang jalan per kecamatan & 3,03 \\
2. Kondisi jalan baik/rusak) & 2,53 \\
3. Rumah tangga pemilik kendaraan roda 2 & 2,02 \\
4. Rumah tangga pemilik kendaraan roda 4 & 1,52 \\
5. Rasio panjang jalan terhadap jumlah kendaraan & 1,01 \\
\hline 1. Peroleh Pajak Bumi dan Bangunan & 9,11 \\
\hline 2. Variasi Mata Pencaharian & 8,11 \\
\hline 3. Indeks Pembangunan Manusia (IPM) & 7,11 \\
\hline Total & $100 \%$ \\
\hline
\end{tabular}

Sumber : PP 19 Tahun 2008 dan Hasil Analisis, 2010

Tabel 2

Total Skore dan Tipologi Kecamatan di Kabupaten Mesuji

\begin{tabular}{|c|l|c|c|c|}
\hline No. & \multicolumn{1}{|c|}{ Kecamatan } & $\begin{array}{c}\text { Nilai Total } \\
\text { Skore }\end{array}$ & $\begin{array}{c}\text { Tipologi } \\
\text { Kecamatan }\end{array}$ & $\begin{array}{c}\text { Kategori } \\
\text { Kecamatan }\end{array}$ \\
\hline 1. & Mesuji & 189 & B & Sedang \\
\hline 2. & Tanjung Raya & 233 & A & Optimal \\
\hline 3. & Rawajitu Utara & 160 & C & Minimal \\
\hline 4. & Mesuji Timur & 238 & A & Optimal \\
\hline 5. & Simpang Pematang & 216 & B & Sedang \\
\hline 6. & Way Serdang & 217 & B & Sedang \\
\hline 7. & Panca Jaya & 176 & B & Sedang \\
\hline
\end{tabular}

Sumber : Hasil Penilaian dan Analisis, 2010

Berdasarkan perhitungan skore terhadap semua kecamatan pada masing-masing variabel atau indikator dan sub indikator kemudian dikalikan dengan jumlah persentase bobot masing-masing sub indikator tersebut dalam tabel di atas, maka dapat diperoleh nilai bobot setiap kecamatan sebagai penentu tipologi kecamatan di Kabupaten Mesuji pada tabel 2. 


\begin{abstract}
Berdasarkan data tersebut dapat dianalisis bahwa secara mayoritas kapasitas kecamatan berada dalam posisi sedang dan bahkan minimal. Meskipun tiplogi dan kapasitas ini tidak berimplikasi terhadap kemampuan sebuah kecamatan untuk menjalankan fungsinya dalam ketatapemerintahan, namun kondisi ini menunjukkan bahwa secara riil banyak kecamatan yang tidak memiliki kemampuan untuk menjalankan fungsinya secara mandiri terutama ketergantungan yang sangat tinggi kepada pemerintahan tingkat atasnya. Bahkan, kondisi ini berbeda dengan status desa yang secara legal justru memiliki kewenangan untuk menyusun anggaran pedapatan dan belanja desanya secara otonom.
\end{abstract}

Dalam posisi tersebut, kecamatan seolah hanya menjadi 'kelembagaan penengah' baik secara vertikal maupun horizontal antara desa dan kabupaten. Secara vertikal, kelembagaan kecamatan dapat berfungsi sebagai penyampung kepentingan antara kabupaten kepada desa dan sebaliknya. Sedangkan dalam fungsi horizontal, kecamatan dapat menjadi mediator dalam kerangka hubungan antara satu desa dengan desa lainnya di kecamatan yang bersangkutan. Fungsi mediasi ini sangat diperlukan agar satu desa dengan desa lainnya tidak terjadi benturan.

Pentingnya memainkan peran sebagai kelembagaan penengah tersebut dikarenakan terutama di wilayah kabupaten yang rural-rural, rentang kendali antara satu desa dengan desa yang lain relatif jauh, apalagi rentang kendali antara desa dengan ibukota kabupaten yang lebih jauh. Hal ini menunjukkan bahwa tipologi kecamatan ke arah yang mandiri (dari $\mathrm{C}$ ke $\mathrm{B}$ dan dari $\mathrm{B}$ ke A) secara nyata belum dapat dilakukan oleh karena ketergantungan dan keterbatasan yang masih sangat tinggi.

\subsection{Kondisi Faktual Kapasitas Keberfungsian Kecamatan}

Secara teori, terdapat empat unsur penunjang kinerja kecamatan yaitu kewenangan, pendanaan, infrastruktur dan sumber daya manusia. Ketidaksediaan terhadap salah satu unsur tersebut akan membuat kecamatan tidak dapat melakukan fungsinya secara optimal. Selaras dengan studi Dharmawan $\quad(2008 ; 12) \quad$ terhadap kapasitas beberapa kecamatan, hasil temuan di kecamatan pada wilayah Kabupaten Mesuji juga sangat sama dengan studi tersebut yang mengindikasikan bahwa fakta kapasitas ketidakberfungsian kecamatan rata-rata melanda kabupaten-kabupaten yang secara riil berada di wilayah kabupaten yang rural.

Pertama tentang kewenangan. Secara normatif, dalam fungsi pemerintahan (pelayanan publik) kecamatan seharusnya memiliki kewenangan (delegatif) yang sangat jelas. Dalam bidang pembangunan seharusnya ada koordinasi dan fasilitasi antara dinas/instansi di kabupaten dengan kecamatan. Dalam hal kemasyarakatan, idealnya kewenangan kecamatan untuk resolusi konflik dan pembinaan masyarakat misalnya juga harus jelas. Sedangkan dalam hal pemberdayaan masyarakat memang dalam regulasi juga kurang jelas.

Analisis terhadap kewenangan ini menunjukkan bahwa meskipun dalam Pasal 126 UU 32/2004 
memungkinkan adanya pelimpahan wewenangan secara delegatif dari bupati kepada camat untuk urusanurusan tertentu, namun fakta membuktikan bahwa hampir tidak ada kewenangan yang didelegasikan kepada kecamatan sehingga kecamatan tetap tidak bisa menjalankan fungsinya secara maksimal. Fakta di kecamatan menunjukkan bahwa dalam pelayanan umum (pemerintahan) kewenangan seringkali tidak jelas, dalam koordinasi pembangunan juga tidak efektif karena kewenangan kecamatan sangat lemah dan dalam bidang kemasyarakatan tanggung jawab camat sangat besar sehingga jika ada konflik di kecamatan seolaholah camat harus berada dalam garda terdepan dalam menyelesaikan konflik tersebut. Sedangkan dalam hal pemberdayaan masyarakat camat tidak emiliki acuan kerja yang jelas.

Kewenangan bupati secara operasional hanya diberikan kepada dinas/instansi sebagai pelengkap pemerintahan kabupaten sesuai dengan bidangnya. Kecamatan yang meskipun memiliki peran yang signifikan namun tidak mendapatkan kewenangan secara tegas. Padahal, dengan posisi kecamatan setara dengan SKPD seharusnya ada kewenangan khusus yang dimiliki kecamatan dalam konteks pelayanan kepada masyarakat. Meskipun dinas pada kenyataannya juga tidak memiliki perangkat teknis sampai tingkat desa, dan sebenarnya dapat mengoptimalkan fungsi kecamatan, namun hal ini juga tidak terjadi. Hal ini membuktikan bahwa sampai saat ini belum ada political will dari bupati untuk mendelegasikan kewenangannya kepada camat, maupun goodwill dari kepala dinas untuk melibatkan kecamatan dalam urusan-urusan tertentu.

Kedua, analisis pendanaan (budgeting) menunjukkan bahwa kecamatan juga tidak memiliki kewenangan dalam hal perencanaan penganggaran sebagaimana dimiliki oleh satuan kerja perangkat daerah (dinas/instansi). Padahal, keduanya memiliki status yang sama. Kewenangan menganggarkan pada institusi kecamatan diambil oleh Sekretariat Daerah sehingga kecamatan hanya menunggu alokasi pendanaan yang disediakan. Dalam konteks hubungan dengan DPRD atau panitia anggaran, jika SKPD lain memiliki kesempatan untuk menyampaikan kebutuhannya secara langsung dan dapat langsung berdialog, maka pihak kecamatan sama sekali tidak pernah dilibatkan dalam hal ini.

Pada akhirnya, pendanaan yang diberikan kepada kecamatan hanya sekedar pendanaan untuk kebutuhan personil dan urusan-urusan administratif. Sedangkan urusan substantif yang sebenarnya melekat pada fungsi kecamatan yang sangat luas tidak diberikan. Kondisi ini membuat kesenjangan yang sangat besar antara tuntutan pelayanan yang sangat tinggi dari masyarakat dengan kapasitas anggaran yang dimiliki oleh kecamatan. Ketidakmampuan dalam hal pendanaan ini menjadi faktor kedua kelemahan kecamatan dalam hal menjalankan fungsinya selain faktor tidak adanya pendelegsian wewenang.

Secara ideal-normatif, dalam bidang pemerintahan seharusnya kecamatan juga menjalankan fungsi penganggaran berbasis kinerja, namun faktanya pendanaan untuk kecamatan sudah dibatasi (sistem plafon) dari sekretariat daerah 
sehingga tidak tipologi kecamatan apapun (A,B atau C) tidak akan mendapatkan perlakuan yang berbeda karena modelnya adalah model seragam. Dalam hal pembangunan memang tidak ada di wilayah kecamatan melainkan ada di dinas teknis kecuali ada pendelegasian wewenang, sehingga dalam hal pembangunan akses kecamatan juga sangat terbatas.

Dalam bidang kemasyarakatan, idealnya dana disediakan secara khusus oleh negara untruk memfasilitasi camat menyelesaikan persoalan-persoalan kemasyarakatan namun faktanya camat seringkali harus menanggung secara pribadi dana-dana yang dibutuhkan untuk menjalankan fungsi tersebut. Dalam pemberdayaan masyarakat pun demikian, anggaran yang besar justru ada di dinas/instansi dalam bentuk penyuluhan, sosialisasi dan sejenisnya, namun faktanya dana tersebut juga dikelola sendiri oleh dinas/instansi meskipun pada pelaksanaannya di lapangan tetap meminta camat untuk memfasilitasi kegiatan pemberdayaan tersebut.

Faktor berikutnya adalah tentang infrastruktur. Dalam menjalankan fungsi pemerintahan, pembangunan, kemasyarakatan dan pemberdayaan masyarakat seharusnya seluruh kecamatan ditopang oleh infrastruktur dan peralatan serta teknologi yang memadai. Secara ideal-normatif semua kebutuhan tersebut disediakan oleh negara, namun kenyataaanya semuanya dirasakan kurang mencukupi sehingga 'memaksa; camat untuk berimprovisasi dalam menanggulangi kelemahan ini. Dalam hal dukungan teknologi misalnya, institusi kecamatan berada dalam keadaan yang sangat memprihatinkan. Hal ini disebabkan oleh rentetan dari ketiadaan kewenangan yang dimiliki kecamatan.

Faktor pendukung terakhir adalah sumber daya manusia. Idealnya kecamatan didukung oleh tenaga (SDM) yang terdidik dan terlatih, namun faktanya tenagatenaga terdidik dan terlatih tersebut justru berada di dinas/instansi. Staf di kecamatan, tidak jarang justru adalah orang-orang bermasalah yang sengaja 'dibuan' dari sekretariat daerah atau dinas/instansi. Persoalan SDM yang dihadapi oleh kecamatan cukup rumit. Kerumitan tersebut disebabkan persoalan SDM bukan hanya sekedar menyangkut tingkat pendidikan yang kurang mencukupi kebutuhan yang berkembang serta keahlian dan ketrampilan para aparatnya yang tidak memenuhi perkembangan. Namun, persoalan SDM juga lebih jauh dari itu kerana menyangkut ketidakmampuan kewirausahaan sosial yang selayaknya dimiliki oleh camat dan aparatur kecamatan sebagai pejabat publik dengan fungsi kemasyarakatan yang melekat pada dirinya.

Hal lain yang selama ini kurang pada aparatur kecamatan adalah standar kemampuan minimal yang dapat menjamin good governance practices di tingkat kecamatan. Kebanyakan keluhan masyarakat yang selama ini dilayani oleh kecamatan seringkali berputarputar pada isu transparansi dan akuntabilitas yang rendah atas dana pungutan yang ditarik oleh pihak kecamatan pada saat warga mengurus apapun di kecamatan. Oleh karena itu, SDM kecamatan harus mampu memiliki kemampuan dan kualifikasi atas tuntutan 
penyelenggaraan good governance tersebut.

\subsection{Rekomendasi Keberfungsian Kelembagaan Kecamatan}

Secara teori, terdapat empat unsur penunjang kinerja kecamatan yaitu kewenangan, pendanaan, infrastruktur dan sumber daya manusia. Ketidaktersediaan terhadap salah satu unsur tersebut akan menjadikan kecamatan tidak mampu menjalankan fungsinya secara baik. Padahal, penguatan kecamatan adalah salah satu kebijakan alternatif yang perlu dilakukan dalam upaya mengurangi keinginan pemekaran daerah kabupaten yang selama ini muncul akibat rentang kendali yang jauh.

Sehubungan dengan tuntutan pemekaran daerah otonom yang dimotivasi oleh tuntutan peningkatan aksesibilitas pelayanan publik, Pratikno (2008:12) menegaskan bahwa pemerintah harus meresponnya dengan memperkuat kecamatan, yaitu:

a. Memposisikan pemerintah kecamatan sebagai basis pelayanan publik, baik pelayanan administratif (KTP, IMB dan lain-lain), maupun pelayanan substantif (pelayanan kesehatan, pendidikan, dan lain-lain). Perbaikan proses pelayanan, seperti gagasan One Stop Service, seharusnya ditempatkan di ibukota pemerintah kecamatan, dan bukan diletakkan di ibukota pemerintahan yang lebih atas.

b. Memposisikan pemerintah kecamatan dalam fungsi kebijakan pembangunan ekonomi, sehingga pusat-pusat pertumbuhan ekonomi bisa berkembang di level kecamatan. c. Merancang desain kelembagaan serta dukungan aparatur dan anggaran untuk pemerintah kecamatan yang memungkinkannya merespon secara cepat perkembangan kebutuhan pelayanan kepada masyarakat.

d. Memekarkan kecamatan sebagai pilihan kebijakan untuk mendekatkan sentra pelayanan kepada masyarakat, daripada memekarkan kabupaten atau kota atau provinsi sebagai daerah otonom yang membutuhkan infrastruktur pemerintahan yang lebih besar.

e. Untuk mengurangi kecenderungan pemekaran kecamatan yang kemudian diikuti oleh pemekaran kabupaten, maka posisi pemerintahan kecamatan perlu ditingkatkan sehingga memberikan kebanggaan sosiokultural bagi masyarakat setempat.

$\quad$ Lima dimensi atau upaya
penguatan kecamatan tersebut
menegaskan kecamatan tetap menjadi institusi penengah yang potensial. Jika di atas dinyatakan bahwa kecamatan memiliki kemampuan secara vertikal sebagai lembaga penengah antara kabupaten dengan desa dan antara satu desa dengan desa yang lainnya, maka dalam lima dimensi tersebut kecamatan mampu menjadi solusi atas berbagai tututan pemekaran daerah kabupaten yang saat ini sedang marak. Jadi, sangat tidak adil apabila 'potensi' kecamatan sebagai 'institusi penengah' tersebut justru dinafikan oleh ketakutan politis bupati untuk tetap tidak memberikan delegasi kewenangan kepada camat dan institusi kecamatan. 
Upaya lainnya yang harus dilakukan terkait dengan kelemahan ruang atau kapasitas kecamatan adalah dengan mensupport space I (delegasi kewenangan) space II (anggaran), space III (anggaran) dan space IV (sumber daya manusia) baik internal maupu eksternal. Regulasi kebijakan perlu dilakukan secara struktural dan fungsional yakni dengan mengupayakan adanya kewajiban bagi bupati/walikota untuk mendelegasikan urusan tertentu kepada camat tanpa bupati/walikota dilanda ketakutan akan kehilangan kekuatan politisnya di depan masyarakat.

Space II dikuatkan dengan cara konsistensi kedudukan. Dengan asumsi bahwa kecamatan memiliki posisi sebagai satuan kerja perangkat daerah, maka kecamatan juga harus diposisikan sama dengan satuan kerja perangkat daerah yang lain yakni memiliki kewenangan menyusun kebutuhan pendanaannya secara mandiri tanpa adanya intervensi. Sepanjang kebutuhan pendanaan tersebut rasional untuk mendukung fungsi pemerintahan, pembangunan, kemasyarakatan dan pemberdayaan masyarakat maka wajar kecamatan memperoleh dukungan pendanaan yang besar pula. Upaya memperkuat space II ini sekaligus akan meningkatkan kapasitas space III yakni terpenuhinya dukungan infrastruktur yang memadai bagi kecamatan untuk dapat menjalankan fungsinya secara optimal.

Tuntutan pengutanan kapasitas pendanaan dan kapasitas infrastruktur, tentunya harus didukung oleh kapasitas space IV yaitu kualitas sumber daya manusia. Selain kompetensi dan kualifikasi minimal sebagai aparatus yang memahami prinsip penyelenggaraan tata pemerintahan yang baik, SDM kecamatan juga harus memiliki kemampuan dasar perencanaan strategis, pengelolaan keuangan serta memiliki jiwa wirausaha dalam rangka memberikan support bagi kebijakan peningkatan pendapatan asli daerahnya; hal ini juga selaras dengan ketentuan dalam UU tahun 2010 yang mengalihkan pajak bumi dan bangunan dari pajak pusat menjadi pajak daerah. Aparatur kecamatan harus menangkap peluang ini dalam rangka peningkatan kapasitas kecamatan khususnya dan pemerintah daerah umumnya.

Penguatan secara internal ini sekaligus dapat dimanfaatkan oleh bupati dalam kerangka menilai kapasitas kepemimpinan jangka panjang seorang camat. Sebagaimana dijalankan saat ini, seorang camat biasanya adalah seseorang yang secara formal lulusan ilmu pemerintahan, oleh karena itu kepemimpinan di kecamatan adalah proses non formal menilai kapasitas seorang camat. Jika hal ini dilakukan, maka korelasi antara tipologi kecamatan dengan kepempinan camat juga dapat diterapkan; seorang yang bisa menjadi camat di kecamatan dengan tipologi A sebelumnya harus pernah menjadi camat di kecamatan bertipologi B dan seterusnya.

Secara eksternal, peningkaatan kapasitas sumber daya manusia juga harus diarahkan secara sosial psikologikal kepada masyarakat (warga kecamatan) tentang perubahan mendasar tugas, kewenangan dan posisi kecamatan saat ini. Pemahaman masyarakat tentang perubahan tersebut menjadi penting dalam kerangka mengurangi berbagai tuntutan dan keluhan yang disampaikan oleh masyarakat 
terhadap pelayanan di kecamatan selama ini yang memang bukan lagi kewenangan camat dan institusi kecamatan untuk dapat menyelesaikannya.

\section{SIMPULAN}

Secara ideal-normatif, pemerintah daerah perlu menyusun tipologi kecamatan di wilayahnya ke dalam tipe $\mathrm{A}, \mathrm{B}$ dan $\mathrm{C}$ untuk melihat kapasitas yang dimiliki oleh masingmasing kecamatan. Kecamatan dengan tipologi A pasti memiliki kemampuan lebih dibanding kecamatan yang memiliki tipologi $\mathrm{B}$ dalam menjalankan fungsi pemerintahan, pembangunan, kemasyarakatan dan pemberdayaan masyarakat dan seterusnya; kecamatan dengan tipologi B pasti memiliki kapasitas yang lebih dibanding kecamatan yang bertipologi C.

Berdasarkan kondisi

kelemahan kecamatan dan jika mengacu pada Gambar 1, maka 'olah' kewenangan dan 'olah' kekuasaan yang dijalankan oleh kecamatan selama ini terbukti tidak mampu mendukung pembangunan, kemasyarakatan dan pemberdayaan masyarakat yang berada di ruang $\mathrm{V}$ akibat daya dukung dan prasayarat yang sangat marginal. Ruang $\mathrm{V}$ yang merupakan ruang pertemuan keempat elemen pendukung keberfungsian kecamatan (wewenang, pendanaan, infrastruktur dan SDM) yang menopang institusi kecamatan. Luas sempitnya space yang ada di ruang $\mathrm{V}$, merefleksikan besar dan kecilnya kapasitas kecamatan untuk menjalankan fungsinya.

Oleh karena itu, upaya penguatan institusi kecamatan, dalam hal ini adalah mengusahakan space di ruang $\mathrm{V}$ yang dapat dilakukan dengan upaya mereposisi kecamatan melalui jalur (a) strukturalisme fungsional yakni perubahan regulasi dan kebijakan, (b) redefinisi dan kategorisasi 'ruang bermain' yang nyaman bagi kecamatan dengan kewajiban kepada kepala daerah (bupati/walikota) untuk dapat mendelegasikan kewenangan minimal, (c) penguatan sumberdaya manusia melalui pengadaan aparatur yang berkualifikasi baik serta memiliki kemampuan kewirausahaan, perencanaan dan kepemimpinan. Selain upaya itu, upaya melalui sosial-psikologikal yakni memberikan penjelasan kepada masyarakat. Namun, jika semua hal tersebut tetap tidak bisa dilakukan, maka transformasi kelembagaan kecamatan dengan meniadakan institusi kecamatan dalam sistem ketata pemerintahan daerah bisa jadi menjadi lebih baik untuk dilakukan. Kewenangan yang selama ini dimiliki oleh kecamatan dapat dilaksanakan sebagian oleh dinas/instansi atau dengan menguatkan peran desa. Hal ini lebih baik daripada kecamatan selalu dihadapkan pada dilema.

\section{DAFTAR PUSTAKA}

Dharmawan, Arya Hadi. 2008. "Kelembaganan dan Tata Pemerintahan Kecamatan”. Pusat Studi Pembangunan Pertanian dan Perdesaan Institut Pertanian Bogor. Bogor.

Drajat, Denden Kurnia dkk. 2010. "Studi Kelayakan Komposisi Kecamatan di Kabupaten Mesuji Provinsi Lampung”. 
Lembaga Penelitian

Universitas Lampung. Bandar

Lampung

Lay, Cornelis. 2002. "Desentralisasi

dan Demokrasi; Kajian

tentang Kecamatan sebagai

Arena Pengembangan

Demokrasi, Pelayanan

Publik, Ekonomi dan

Intermediary" FISIPOL

UGM dan Ford Foundation.

Yogykarta.

Mukhlis, Maulana. 2010.

"Kecamatan; Wilayah atau Perangkat Daerah".

Lampung Post, Bandar Lampung

Pratikno. 2008. "Usulan Perubahan Kebijakan Penataan Daerah (Pemekaran dan Penggabungan Daerah”. Democratic Reform Support Program dan United States Agency International Development. Jakarta

Republik Indonesia. 2008. "Peraturan Pemerintah Nomor 19 Tahun 2008 tentang Kecamatan". Biro Dokumentasi Kementerian Dalam Negeri. Jakarta

Triputro, R.W. 2005. "Pembangunan Otonomi Daerah”. Program Studi Ilmu Pemerintahan STMPD dan AMPD Press. Yogyakarta. 